\title{
Penegakan Hukum Terhadap Pelaku Perbuatan Main Hakim Sendiri (Studi di Wilayah Hukum Kepolisian Resor Semarang Barat)
}

\author{
Aprisylia Dwi Hapsari, Rochmani \\ Fakultas Hukum, Universitas Stikubank (UNISBANK) Semarang \\ E-mail :aprusylia@gmail.com, Rochmani@edu.unisbank.ac.id
}

\begin{abstract}
ABSTRAK
Perbuatan main hakim sendiri merupakan suatu pelanggaran yang masih sering terjadi di masyarakat sekitar kita. Hal tersebut melanggar ketentuan ketentuan pasal 170 ayat (1) dan (2) KUHP, pasal 351 ayat (2) dan (3) KUHP, pasal 354 ayat (1) dan (2) KUHP. Pelanggaran terhadap perbuatan main hakim sendiri tidak dibenarkan karena seolah - olah masyarakat sebagai pelaku perbuatan main hakim sendiri mengabaikan proses hukum yang berlaku di Indonesia. Maka perlu adanya perlindungan bagi tersangka atau korban main hakim sendiri secara hukum walaupun ia sebagai pelaku tindak pidana. Hal tersebut bertujuan agar tercapainya keadilan dan proses hukum yang ada di Negara ini. Perumusan masalah penelitian ini adalah Apa Faktor - faktor penyebab terjadinya perbuatan main hakim sendiri, Bagaimana penegakan hukum terhadap pelaku perbuatan main hakim sendiri (Studi di Wilayah Hukum Kepolisian Resor Semarang Barat). Tipe penelitian yang digunakan dalam penelitian ini adalah secara yuridis normatif. Spesifikasi penelitian bersifat deskriptif analitis. Penelitian ini menggunakan dua sumber sember data: data primer dan data skunder. Metode penyajian data dalam penelitian dilakukan dengan cara deskriptif. Analisis yang di pergunakan dalam penulisan skripsi ini adalah kualitatif. Hasil penelitian menunjukan bahwa, Faktor - faktor penyebab terjadinya perbuatan main hakim sendiri yaitu rasa sepontan yang timbul dari sekelompok masyarakat yang bersumber dari faktor tekanan sosial, kurang kepercayaannya masyarakat terhadap aparat penegak hukum, kurangnya pengetahuan masyarakat yang melakukan main hakim sendiri mengenai hukum dan masyarakat sibuk mengabadikan momen main hakim sendiri dengan ponsel ketimbang harus melerai. Penegakan hukum terhadap pelaku perbuatan main hakim sendiri (Studi di Wilayah Hukum Kepolisian Resor Semarang Barat) dengan melakukan, mengatasi, dan meminimalisasi terjadinya perbuatan main hakim sendiri baik itu dari kebijakan kebijakan penal (represif) sesuai pasal 27 ayat (1) UUD 1945, pasal 170 ayat (1) dan (2) KUHP, pasal 351 ayat (2) dan (3) KUHP, pasal 338 KUHP pasal 354 ayat (1) dan (2) maupun non penal (preventif) dilakukan dengan mengadakan penyuluhan pada masyarakat di daerah daerah yang di anggap tempat maraknya kejadian main hakim sendiri dan melaksanakan patroli rutin.
\end{abstract}

Kata Kunci : Faktor, Penegakan, Perbuatan Main Hakim Sendiri. 


\begin{abstract}
Vigilantism itself is an offense that still often occurs in the community around us. This violates the provisions of article 170 paragraph (1) and (2) of the Criminal Code, article 351 paragraph (2) and (3) of the Criminal Code, article 354 paragraph (1) and (2) of the Criminal Code. Violations of vigilantism are not justified because it is as if the community as the perpetrators of vigilantism ignores the legal process in force in Indonesia. Then there needs to be protection for the suspect or victim of vigilantism even though he is a criminal. It aims to achieve justice and legal processes in this country. The formulation of the problem of this research is What are the factors - factors that cause the occurrence of vigilante actions, How is law enforcement against perpetrators of vigilante acts (Study in the Legal Area of the West Semarang District Police). The type of research used in this study is juridical normative. The research specifications are analytical descriptive. This study uses two sources of cracked data: primary data and secondary data. The method of presenting data in research is done in a descriptive way. The analysis used in writing this thesis is qualitative. The results showed that, the factors that caused the act of vigilantism were spontaneous arising from a group of people who came from social pressure factors, lack of public trust in law enforcement officials, lack of knowledge of people who conduct vigilante about the law and busy people capture the moment of vigilante with a cellphone rather than having to break up. Law enforcement against perpetrators of vigilante conduct (Studies in the Legal Area of the West Semarang District Police) by conducting, overcoming, and minimizing the occurrence of vigilante acts both from the policy of penal policy (repressive) in accordance with article 27 paragraph (1) of the 1945 Constitution, article 170 paragraph (1) and (2) KUHP, article 351 paragraph (2) and (3) KUHP, article 338 KUHP article 354 paragraph (1) and (2) as well as non-penal (preventive) is done by conducting counseling to the community in the area - areas considered to be the scene of vigilantism and carrying out routine patrols.
\end{abstract}

Keywords: Factors, Enforcement, Self-Performing Judges.

Pendahuluan

Indonesia adalah negara hukum, berdasarkan pasal 1 ayat (3) UndangUndang Dasar Negara Republik Indonesia Tahun 19945. Dari penjelasan tersebut dapat di katakan bahwa masyarakat indonesia adalah masyarakat yang taat akan hukum dalam setiap tindakan dan prilaku yang dilakukan oleh masyarakat tersebut sudah sesuai dengan peraturan perundang undangan.

Perkembangan kehidupan masyar akat yang begitu cepat sebagai hasil dan proses pelaksanaan pembangunan di segala bidang kehidupan sosial, politik, ekonomi, keamanan, dan budaya telah membawa pula dampak negatif berupa peningkatan kualitas dan kuantitas berbagai macam kejahatan yang 
sangat merugikan dan sangat meresahkan masyarakat. ${ }^{1}$

Salah satu upaya agar hukum dapat efektif berlaku di masyarakat adalah dengan adanya penegakan hukum. Penegakan hukum adalah proses dilakukannya upaya untuk tegaknya atau berfungsinya norma - norma hukum secara nyata sebagai pedoman prilaku manusia di dalam melakukan kontak sosial. $^{2}$

Asas penegakan hukum yang cepat, tepat, sederhana dan biaya ringan saat ini belum sepenuhnya mencapai sasaran seperti yang di harapkan masyarakat pada umumnya. Masih banyak di temui sikap dan prilaku aparat penegak hukum yang merugikan masyarakat maupun keluarga korban. ${ }^{3}$

Kekerasan masyarakat adalah kekerasan yang di lakukan kelompok masyarakat akibat ketidakadilan, penindasan, represi, yang di alami oleh kelompok masyarakat. Pada umumnya, kekerasan masyarakat terjadi akibat tekanan ekonomi sehingga masyarakat melakukan kekerasan.

Dalam maraknya kasus perbuatan main hakim sendiri (eigenrichting), di awali dengan maraknya kejahatan yang ada di dalam masyarakat. Masyarakat memberikan reaksi apabila pelaku

kejahatan tersebut

${ }^{1}$ Soejono, 1996, Kejahatan dan Penegakan Hokum di Indonesia, Jakarta: PT. Rineka Cipta, hlm 1.

${ }^{2}$ Sudarto, 2006, Kapita Hokum Pidana, bandung, hlm 112.

${ }^{3}$ Soejono, 1996, Kejahatan dan Penegakan Hokum di Indonesia, Jakarta, PT. Rineka Cipta, Jakarta, hlm 2 JURNAL ILMU HUKUM.LEGAL.OPINION.Edisi 2, Volume3, Tahun 2015. tertangkap tangan oleh masyarakat. Dalam penegakan terhadap pelaku main hakim sendiri kepolisian mengalami banyak kesulitan, polisi yang mempunyai tugas sebagai penyidik, mengalami kesulitan dalam hal informasi. Suatu perkara main hakim sendiri informasi dan pelaku itu berasal dari masyarakat yang sama, sehingga ada naluri untuk saling melindungi. Polisi juga mengalami kesulitan dalam hal jumlah masa, dalam suatu perbuatan main hakim sendiri yang sering di lakukan secara bersama - sama dan melibatkan banyak orang yang mempersulit kinerja dari kepolisian untuk menyelesaikan perkara perbuatan main hakim sendiri serta korban atau pelaku perbuatan main hakim sendiri tidak mau melaporkan reaksi masyarakat yang menyebabkan kegiatan korban.

Pada hakikatnya manusia mempunyai hak _ mendasar dalam dirinya baik itu sebelum lahir ataupun baik yang ada ketika sudah lahir. Begitu pula pada pelaku tindak pidana yang mempunyai hak - hak yang sama dimata hukum yang telah di cantumkan dalam pasal 27 ayat (1) UUD 1945 " bahwa segala warga negara sama kedudukannya di dalam hukum dan pemerintahan dan wajib menjunjung hukum dan pemerintahan tanpa ada pengecualian ". 4 Peraturan

\footnotetext{
${ }^{4}$ Voice of human rights, Hak-hak Tersangka Dalam Kuhap, http://www.vhrmedia.com/yhrcorner/paduan,HAK-HAK-TERSANGKA-

DALAM-KUHAP-20-html, di akses pada tanggal 2019/03/28, $19.30 \mathrm{Wib}$.
} 
perundang - undangan khususnya Kitap Undang - Undang Hukum Pidana belum mengatur secara khusus mengenai tindakan main hakim sendiri, akan tetapi bukan berarti KUHP tidak dapat di terapkan sama sekali jika terjadi perbuatan tindakan main hakim sendiri. Terdapat pasal - pasal yang mengatur mengenai tindakan main hakim sendiri yaitu, Pasal 170 tentang kekerasan, pasal 351 tentang penganiayaan.

Peristiwa main hakim sendiri yang dilakukan oleh masyarakat biasanya terjadi jika pelaku tindak pidana tertangkap di tempat ramai (jalan raya, halte bus, mall, pasar) dan tidak segera dilaporkan atau dibawa ke pihak yang berwenang.

Faktor penyebab terjadinya perbuatan main hakim sendiri biasanya terjadi karena kurangnya kepercayaan masyarakat terhadap aparat penegak hukum, rendahnya pendidikan/pengetahuan masyarakat yang melakukan main hakim sendiri mengenai hukum, masyarakat seringkali merasa bingung ketika membutuhkan suatu pertolongan hukum karena kurangnya pengetahuan terhadap hukum sehingga ketika terjadi suatu tindakan kejahatan yang dilakukan oleh pihak lain, masyarakat yang juga sebagai pelaku ini akan langsung melakukan tindakan main hakim sendiri tanpa memikirkan dari segi hukum.

Perilaku-perilaku kejahatan yang dilakukan oleh pelaku kejahatan sudah sangat meresahkan masyarakat, sehingga

masyarakat melampiaskan amarahnya dengan menghajari

dan memukulinya. ${ }^{5}$

Seperti contoh kasus yang di alami oleh remaja yang sedang berboncengan dengan temannya dan terlibat kecelakaan ( tabrak lari ) di depan Hotel UTC Sampangan Semarang.

Pada hari senin, tanggal 18 Maret 2019 sekitar pukul 21.30 WIB korban berboncengan dengan temannya menaiki sepeda motor terlibat kecelakaan ( tabrak lari ) di depan Hotel UTC Sampagan Semarang lalu korban melarikan diri dan saat di depan Sam Poo Kong Korban dihadang oleh salah satu pelaku perbuatan main hakim sendiri namun kedua tetap melajukan kendaraannya hendak kabur, tetapi justru Korban terjatuh dan teman Korban berhasil kabur.

Setelah teman korban mengetahui teman korban terjatuh, Teman korban kembali arah guna membantu korban yang jatuh. Pada saat itulah korban dipukuli dan diinjak oleh massa atau para pelaku, selang beberapa menit seseorang dengan rambut cepak ( model aparat ) membantu pengamanan kedua korban. Korban yang jatuh di bawa ke RS Wongsonegoro Ketileng Semarang sedangkan teman yang satu di bawa pulang oleh orangtuanya.

Permasalahan Laka Lantas sudah diselesaikan secara kekeluargaan di Unit Laka Polrestabes Semarang dan untuk permasalahan pemukulan dan tindakan kekerasan fisik terhadap

\footnotetext{
${ }^{5}$ http://www.qureta.com, di akses pada tanggal 2019/03/27, $20.28 \mathrm{Wib}$.
} 
kedua korban. Orang tua korban melaporkan ke Polrestabes Semarang kemudian laporan polisi dilimpahkan ke Polsek Semarang Barat guna pengusutan lebih lanjut.

Fenomena tersebut merupakan reaksi sepontan masyarakat melihat aksi kejahatan yang marak di sekitar kita. Ini merupakan cermin untuk pihak kepolisian karena masyarakat merasa tidak terayomi dan mencari keadilannya dengan cara sendiri. Kehidupan masyarakat lebih dominan berlaku hukum rimba ketimbang hukum yang brlaku. Dengan melihat banyaknya kasus main hakim sendiri disekitar kita yang tidak terselesaikan hanya sampai penyelidikan atau bahkan tidak diperiksa sama sekali itu membuat tertarik untuk menulis penulisan hukum dengan judul "PENEGAKAN HUKUM TERHADAP PELAKU PERBUATAN MAIN HAKIM SENDIRI (STUDI DI WILAYAH HUKUM KEPOLISIAN RESOR SEMARANG BARAT).”

Berdasarkan uraian dari latar belakang yang telah dikemukakan diatas, maka perumusan masalah yang timbul dalam penelitian adalah sebagai berikut :

1. Apa faktor - faktor penyebab terjadinya perbuatan main hakim sendiri ?

2. Bagaimana penegakan hukum terhadap pelaku perbuatan main hakim sendiri (Studi di wilayah hukum kepolisian Resor Semarang Barat)?

\section{Metode Penelitian}

Penelitian tentang "Penegakan Hukum Terhadap Pelaku Perbuatan Main Hakim Sendiri (Studi di Wilayah Hukum Kepolisian Resor Semarang Barat)" ini merupakan suatu penelitian hukum dengan menggunakan cara pendekatan yuridis normatif yaitu merrupakan suatu penelitian yang menekankan pada ilmu hukum serta menelaan kaidah - kaidah hukum yang berlaku.

Spesifikasi penelitian ini adalah deskriptif analitis, karena hasil penelitian ini menggambarkan peraturan perundang - undangan yang berlaku yang dikaitkan dengan dan dianalisa dengan teori - teori hukum dan suatu keadaan objek yang menjadi masalah dalam penelitian.

Data yang dikumpulkan adalah data yang berhubungan dengan peraturan perundang - undangan yang berlaku yakni Kitab Undang - Undang Hukum Pidana Terdapat pasal - pasal yang mengatur, Pasal 170 tentang kekerasan, pasal 351 tentang penganiayaan serta pengumpulan data dalam penelitian ini menggunakan studi pustaka dan wawancara.

\section{Pembahasan}

\section{Faktor - Faktor Penyebab Terjadinya Perbuatan Main Hakim Sendiri}

Faktor - faktor dalam penyebab terjadinya perbuatan main hakim sendiri berdasarkan wawancara terhadap pelaku yang melakukan perbuatan main hakim sendiri terhadap kasus tabrak lari di depan hotel UTC semarang, beberapa faktor penyebab terjadinya 


\begin{abstract}
perbuatan main hakim sendiri adalah adanya ketidak percayaan masyarakat sekitar terhadap penegakan hukum, serta masyarakat menilai hukuman yang di berikan oleh aparat penegak hukum masih belum adil dan sentimpal dengan apa yang di perbuat si pelaku kejahatan, adanya sifat spontan dari sekelompok orang yang bersumber dari faktor tekanan sosial,

banyaknya pengangguran dan kondisi ekonomi yang sulit membuat sekelompok orang yang berada di sekitar tempat kejadian menjadi frustasi dan tidak berpikiran panjang, tindakan main hakim sendiri inilah yang menjadi lahan pelampiasan dari tekanan jiwa tersebut, kebanyakan masyarakat sekitar tidak mengetahui bagaimana cara melaporkan tindak kejahatan dan jarak antara tempat kejadian dengan kantor polisi yang jauh. Hal ini menyebabkan polisi datang setelah penjahat atau yang di duga penjahat ini sudah habis dihakimi masa saat kejadian berlangsung tidak adanya pelerai atau pihak yang berusaha menghalangi tindakan main hakim sendiri tersebut. Dizaman yang berteknologi tinggi ini malah banyak masyarakat sibuk mengabadikan momen main hakim sendiri dengan ponsel genggamnya bukan menjadi penengah. ${ }^{6}$
\end{abstract}

${ }^{6}$ Wawancara Gigih, kasat reskrim polsek semarang
Jika di lihat dari unsur - unsur perbuatan yang di lakukan pelaku perbuatan main hakim sendiri ini bisa di mintai pertanggung jawabannya dengan beberapa pasal yang ada dalam kitab Undang Undang Hukum Pidana seperti :

1. Pasal 170 ayat 1 dan 2

a. Barang siapa terang terangan dan dengan tenaga bersama menggunakan kekerasan terhadap orang atau barang.

b. Jika perbuatan kekerasan tersebut mengakibatkan luka berat

c. Jika perbuatan kekerasan tersebut mengakibatkan maut

2. Pasal 351 ayat (2) dan (3) tentang penganiayaan

a. Yaitu jika perbuatan tersebut mengakibatkan luka - luka berat

b. Jika perbuatan tersebut mengakibatkan kematian atau hilangnya nyawa seseorang.

3. Pasal 354 ayat (2) dan (3) tentang penganiayaan berat

4. Pasal 4 dan pasal 5 ayat (1) Undang - undang no. 39 tahun 1999 tentang hak asasi manusia yang menyatakan setiap orang berhak untuk hidup dan memperoleh perlakuan dan perlindungan yang sama sesuai dengan martabat kemanusiaan didepan hukum. 
Dari kasus yang di alami wahyu, krisna dan bagus ini mereka mengaku hanya timbul rasa kasian terhadap korban tabrak lari, mereka juga hanya muncul rasa sepontan karena banyaknya sekelompok orang yang berteriak tabrak lari sehingga terjadi perbuatan main hakim sendiri yang di dasari oleh tidak berfikir panjangnya dalam menyelesaikan permasalahan dan timbulah rasa mengadili masyarakat secara sepontan dan cepat, termasuk beramai - ramai melakukan pemukulan dan pengroyokan mengakibatkan korban yang masih di bawah umur ini, mengalami luka berat hingga di larikan ke rumah sakit.

Negara Indonesia merupakan negara hukum dimana semuanya ada yang mengatur tetapi seolah masyarakatnya enggan menyelesaikan masalah dengan hukum. Tindakan main hakim sendiri dapat diredam dengan cara menghilangkan faktor - faktor yang menjadi pemicunya antara lain :

1. Harus adanya tindakan tegas dari aparat penegak hukum dalam menangani sebuah kasus kejahatan.

2. Dalam menangani kasus harus dilakukan secara transparan agar timbulnya kepercayaan pada masyarakat.

3. Masyarakat juga harus diberikan kesadaran bahwa tindakan main hakim sendiri bukanlah tindakan yang menyelesaikan masalah tetapi malah menambah masalah baru.
Penyelesaian masalah tidak harus di selesaikan dengan tindakan sendiri tanpa melawan kaidah hukum yang berlaku, melainkan sudah melalui peraturan pemerintah atau Undang - undang. Meskipun pihak - pihak pembentuk peraturan merupakan orang - orang yang dianggap mampu mewakili masyarakat, tetapi tidak mungkin pihak - pihak tersebut mengerti semua kepentingan kepentingan masyarakat yang di wakilinya, oleh karenanya adalah suatu yang wajar apabila pada akhirnya terdapat perbedaan antara pola - pola prilaku yang diharapkan oleh kaidah - kaidah hukum dengan pola prilaku yang di harapkan masyarakat, sebagai akibat adanya kepentingan dan pola prilaku antara pembentuk hukum dan masyarakat sebagai objek hukum. Sebab bagaimanapun juga isi dari produk hukum yang baik seharusnya adalah terdiri dari cerminan aspirasi masyarakat, bukan berisi pemaksaan kepentingan para pembuatnya.

\section{Penegakan Hukum Terhadap Pelaku Perbuatan Main Hakim Sendiri (Studi di Wilayah Hukum Kepolisian Resor Semarang Barat)}

Fenomena perbuatan main hakim sendiri yang marak terjadi akhir akhir ini merupakan salah satu masalah sosial yang sangat 
memprihatinkan dalam kehidupan bermasyarakat dan bernegara. Sebagai salah satu masalah sosial maka, kebijakan sosial dapat di lakukan untuk menanggulangi, mengatasi dan meminimalisasi terjadinya masalah sosial perbuatan main hakim sendiri baik itu dari kebijakan penal maupun non penal.

Di kota Semarang sendiri terdapat banyak kasus tentang perbuatan main hakim sendiri yang bermunculan baik pada pelaku tindak pidana pencurian, perampokan, tabrak lari bahkan sampai kasus kumpul kebo (mesum) yang tertangkap tangan dan menjadi korban main hakim sendiri disemarang.

Setelah dilakukan penyelidikan, Anggota Reskrim Polsek Semarang Barat berhasil mengamankan tujuh orang pelaku, untuk selanjutnya dilakukan pemeriksaan. Setelah dilakukannya pemeriksaan terhadap tujuh orang pelaku, empat pelaku diantaranya masih dibawah umur sehingga tidak di lakukan penahanan hanya saja pelaku di wajibkan wajib lapor setiap hari senin dan kamis di Polsek Semarang Barat. Sedangkan tiga orang pelaku yang sudah dewasa tetap dilakukan penahanan dan di kenai pasal $76 \mathrm{C}$ ayat 2 Undang Undang RI NO.35 Tahun 2014 tentang perubahan atas Undang Undang No. 23 Tahun 2002 tentang perlindunan anak.

Berdasarkan laporan dari orang tua korban, maka tindakan yang di lakukan oleh pihak Kepolisian
Resor Semarang Barat terhadap kejadian tersebut yaitu : menerima laporan, melakukan penyelidikan, penyidikan, penangkapan, dan penahanan. $^{7}$

1. Menerima laporan

Pada kasus perbuatan main hakim sendiri di awali dengan laporan dari korban yang dihakimi masa atau keluarga korban atau pihak ke tiga dari korban. Laporan tersebut di dasari karena adanya suatu kekerasan yang di alami oleh korban, ( sekaligus tersangka yang di hakimi masa )pada saat penangkapan atau pengejaran yang di alaminya. Karena menurut butiran pasal Undang - undang Dasar 1945 manusia dimata hukum sama rata, hal itu menjelaskan bahwa baik pejabat pemerintah rakyat biasa ataupun tersangka mempunyai perlindungan hukum sama rata.

2. Penyelidikan dan Penyidikan

Penyidikan oleh reskrim pihak Kepolisian Resor Semarang Barat terhadap kasus perbuatan main hakim sendiri merupakan proses penal untuk menyelesaikan masalah hukum. Pelaksanaannya penyidikan dilakukan setelah adanya laporan atas suatu tindak pidana, bertujuan untuk menemukan suatu alat bukti yang sah menurut Undang undang yang berlaku. Dalam

\footnotetext{
${ }^{7}$ Wawancara dengan Bapak Gigih Selaku Kepala Reskrim Kepolisian Resort Semarang Barat/2019/04/16
} 
prosesnya polisi mengumpulkan beberapa alat bukti yang sah serta meminta keterangan saksi - saksi pada saat terjadinya perkara guna menemukan titik terang pada suatu peristiwa pidana dan menemukan tersngkanya.

3. Penangkapan

Kepolisian Resor Semarang Barat telah berhasil menangkap tujuh orang pelaku dan empat pelaku masih dibawah umur sehingga tidak dilakukan penahanan dan wajib lapor. Tiga orang pelaku yaitu wisnu, krisna dan bagus yang sudah dewasa di lakukan penahanan.

4. Penahanan

Tanggal 23 maret 2019 telah di tahan di rumah tahanan Negara di Polsek Semarang Barat, 3 tersangka laki - laki bernama wahyu, krisna dan bagus. Selanjutnya dibuatkan berita acara penahanan tanggal 23 Maret 2019 dengan nomor perkara No na : BP / 05 / III / 2019.

Penahanan ini merupakan suatu upaya untuk mencegah pelaku melarikan diri dan menghilangkan barang bukti, penahanan dilakukan untuk kepentingan penyidikan suatu tindak pidana main hakim sendiri yang melanggar hak asasi manusia untuk tetap mendapatkan perlindungan hukum. Penahanan yang dilakukan oleh penyidik sesuai dengan pasal 20 ayat 1 KUHAP.

Unsur - unsur yang terkait dengan tindak pidana yang di lakukan oleh para tersangka
( Tersangka I Wahyu, Tersangka II Krisna dan tersangka III Bagus ) adalah unsur main hakim sendiri dengan melakukan terang terangan dan dengan tenaga bersama menggunakan kekerasan terhadap orang atau barang. Dikarenakan wahyu, krisna dan bagus melakukan itu terhadap orang atau anak yang masih di bawah umur, ketiga tersangka tersebut di kenakan Perkara Kekerasan terhadap anak Pasal $76 \mathrm{C}$ ayat $2 \mathrm{UU}$ RI NO.35 Tahun 2014 tentang perubahan atas UU No. 23 Tahun 2002 tentang perlindungan anak. Pasal1 ayat (1) dan (2)

(1) anak adalah seseorang yang belum berusia 18 tahun, termasuk anak yang masih dalam kandungan.

(2) perlindungan anak adalah segala kegiatan untuk menjamin dan melindungi Anak dan hak - haknya agar dapat hidup, tumbuh, berkembang dan beradaptasi secara optimal sesuai dengan harkat dan martabat kemanusiaan, serta mendapat perlindungan

dari Kekerasan dan Diskriminasi.

Adapun upaya - upaya yang di lakukan pihak kepolisian resor semarang barat dalam penanganan tindak pidana main hakim sendiri adalah

1. Upaya preventif dengan menggunakan cara ;

a. mengadakan penyuluhan pada masyarakat di daerah - daerah yang dianggap 
tempat maraknya kejadian main hakim sendiri

b. dilakukan untuk mencegah tindak pidana main hakim sendiri yang terjadi di wilayah hukum polsek Semarang Barat. Patroli di lakukan di daerah rawan tindakan kriminal saat malam hari. Patroli ini biasanya disebut dengan oprasi pekat yang mengedepankan fungsi resort kriminal'

2. Upaya represif

Melaksanakan penegakan hukum secara tegas yaitu melakukan penyelidikan di daerah yang sering terjadi tindak pidana main hakim sendiri, melakuka penangkapan terhadap pelaku perbuatan main hakim sendiri. Selain mengadakan operasi pekat seperti contohnya mengadakan patroli setiap malam hari di jalan - jalan rawan tindakan pidana kriminal.

\section{Simpulan}

Faktor - faktor penyebab terjadinya perbuatan main hakim sendiri terjadi karena adanya rasa sifat sepontan dari sekelompok orang atau masyarakat yang bersumber dari faktor tekanan sosial, banyaknya pengangguran, dan kondisi ekonomi yang sulit membuat masyarakat menjadi frustasi dan tidak berfikiran panjang, tindakan main hakim sendiri inilah, yang menjadi lahan pelampiasan dari tekanan jiwa tersebut, masyarakat tidak mengetahui bagaimana cara melaporkan tindak kejahatan dan jarak antara tempat kejadian dengan kantor polisi yang jauh. Hal ini menyebabkan polisi datang setelah pejahat atau yang di duga penjahat ini sudah habis di hakimi masa, tidak adanya pelerai atau pihak yang berusaha menghalangi tindakan main hakim tersebut. Banyak masyarakat sibuk mengabdikan momen main hakim sendiri dengan ponsel genggamnya dibandingkan menjadi penengah dan rasa kurangnya kepercayaan masyarakat terhadap aparat penegak hukum.

Penegakan Hukum Terhadap Pelaku Perbuatan Main Hakim Sendiri Studi di Wilayah Hukum Kepolisian Resor Semarang Barat sebagai salah satu masalah sosial, maka kebijakan sosial dapat di lakukan untuk menanggulangi, mengatasi dan meminimalisasi terjadinya masalah sosial perbuatan main hakim sendiri baik itu dari kebijakan penal (represif) maupun non penal (preventif).

Kebijakan penal (represif) dilakukan dengan melaksanakan penegakan hukum secara tegas sesuai Pasal 27 ayai (1) UUD 1945, Pasal 170 ayat (1) dan (2) KUHP, Pasal 338 KUHP, Pasal 351 ayat (2) dan (3) KUHP, Pasal 354 ayat (1) dan (2) dan melakukan penyelidikan di daerah yang sering terjadi tindak pidana main hakim sendiri.

Kebijakan non penal (preventif) dilakukan dengan mengadakan penyuluhan pada masyarakat di daerah - daerah yang dianggap tempat maraknya kejadian main hakim sendiri, 
melaksanakan patroli sesuai dengan situasi dan kondisi.

\section{Saran}

Sebaiknya pihak kepolisian terus memberikan rasa keamanan serta keadilan dengan cara mengoptimalkan proses penegakan hukum dan melakukan upaya sosialisasi terhadap masyarakat supaya lebih sadar akan hukum dengan menghargai proses proses penegakan hukum serta masyarakat juga harus menghargai hak - hak setiap warganegara.

\section{Daftar Pustaka}

\section{Literatur :}

Adimas.penulisan hukum, 2012, Penegakan Hukum Oleh Pelaku Tindakan Main Hakim Sendiri, fak.hukum, Universitas Diponegoro.

Ali Zainudin, Sosiologi Hukum, Jakarta, Sinar Grafika, hlm 58.

Arif Nawawi Barda, Masalah Penegakan Huku, hlm 14

Hamzah Andi, 1986, Kamus Hukum, Jakarta: Ghalia Indonesia, hlm 167.

Kadir Abdul Muhammad, 2014, Hukum dan Penelitian Hukum. PT. Citra Aditya Bakti, hlm 134.

Kuffal Hma, 2010, Penerapan KUHAP Dalam Praktik Hukum, Edisi revisi, malang: Katalog Dalam terbitan, hlm131,132

Marzuki Mahmud Peter, 2008, Pengantar Ilmu Hukum, Jakarta: kencana prenada media groub, hlm 60 .
Redaksi sinar grafika, 2010,KUHAP LENGKAP,jakarta, hlm.28

Sihombing M Justin, 2005, Kekerasan Terhadap Masyarakat Marginal, narasi, Yogyakarta, hlm 25.

Sudarto, 2009, HUKUM PIDANA I Edisi Revisi. Semarang, hlm 14. Sudarto, 2009,. HUKUM PIDANA I Edisi Revisi. Semarang, hlm 13. Suteki, Makalah Penegakan Hukum.hlm 1

Soejono, 1996, Kejahatan dan Penegakan Hokum di Indonesia, Jakarta: PT. Rineka Cipta, hlm 1.

Sudarto, 2006, Kapita Hokum Pidana, bandung, hlm 112.

Tatal Bastian, 1992, Pokok-pokok Tata Hukum di Indonesia, Jakarta: Gramedia pustaka Utama, hlm. 68. 